\title{
STRATEGI PEMASARAN PRODUK INDUSTRI KREATIF MENGGUNAKAN ALGORITMA K-MEANS CLUSTERING BERBASIS PARTICLE SWARM OPTIMIZATION
}

\author{
Oding Herdiana ${ }^{1}$, Shanti Maulani ${ }^{2}$, Eryan Ahmad Firdaus ${ }^{3}$ \\ ${ }^{1}$ Universitas Pendidikan Indonesia \\ ${ }^{2}$ Akademi Keperawatan RS.Dustira \\ ${ }^{3}$ Sekolah Tinggi Manajemen Informatika dan Komputer LIKMI \\ Email: ${ }^{1}$ oding.herdiana@upi.edu, ${ }^{2}$ shanti.maulani@ akperrsdustira.ac.id, \\ 3 eryan.ahmad@gmail.com
}

\begin{abstract}
Abstrak
Adanya sumber data UMKM yang melimpah dapat digunakan untuk menggali informasi. Klasifikasi ialah teknik menggali data yang tersembunyi dalam data mining. Metode untuk klasifikasi data mining salah satunya dengan algoritma Support Vector Machine (SVM). Algoritma SVM telah membuktikan hasil yang optimal dari algoritma KKN, Decision Tree dan Linear Regresion. Dalam proses klasifikasi, hasil akurasi dan efisiensi waktu yang diperoleh sangat penting. Maka diperlukan optimasi agar meningkatkan akurasi dan efisiensi waktu saat proses klasifikasi. Optimasi algoritma SVM yang dilakukan menggunakan algoritma K-Means untuk proses clustering dan kontinu pada data UMKM dan Particle Swarm Optimization (PSO) digunakan untuk proses seleksi fitur. Tulisan ini bertujuan untuk mendapatkan optimasi akurasi dari data berupa jenis usaha, usaha dan omset. Berdasarkan hasil pembahasan metode SVM dengan menggunakan K-Means dan PSO memberikan akurasi rata-rata sebesar 55\% namun lebih rendah 0,12\% dibandingkan dengan SVM dengan menggunakan PSO saja.
\end{abstract}

Kata Kunci: UMKM, Clustering, K-Means, SVM, PSO.

\begin{abstract}
The existence of abundant UMKM data sources can be used to dig up information. Classification is one of the techniques to explore hidden data owned by data mining. One of Data mining classification methods is the Support Vector Machine (SVM) algorithm. The SVM algorithm has proven better results than the KKN, Decision Tree and Linear Regression algorithms. In the classification process, the accuracy and time efficiency results obtained are very important. So optimization is needed in order to increase accuracy and time efficiency during the classification process. The optimization of the SVM algorithm is carried out using the K-Means algorithm for the clustering and continuous process on UMKM data and the feature selection process uses Particle Swarm Optimization (PSO). This paper aims to optimize the accuracy of the data in the form of business type, business and turnover. From the results of the discussion, it can be concluded that the SVM method using K-Means and PSO gives an average accuracy of $55 \%$ but $0.12 \%$ lower than SVM using PSO alone.
\end{abstract}

Keywords: UMKM, Clustering, K-Means, SVM, PSO. 
JURNAL NUANSA INFORMATIKA

Volume 15 Nomor 2, Juli 2021
p-ISSN : 1858-3911, e-ISSN : 2614-5405

https://journal.uniku.ac.id/index.php/ilkom

\section{PENDAhuluan}

Industri kreatif adalah industri yang berasal dari pemanfaatan keterampilan, kreativitas, dan bakat yang dimiliki individu dalam menciptakan kesejahteraan dan lapangan pekerjaan [2]. Strategi pemasaran industri kreatif dengan akurat sangatlah penting, karena hasil prediksi yang akurat dapat membuat kebijakan yang tepat [3].

Metode culstering merupakan proses pengelompokan data dalam kelas-kelas atau cluster-cluster sehingga data dalam suatu cluster memiliki tingkat persamaan yang tinggi satu dengan yang lainnya tetapi sangat berbeda dengan data dalam cluster lain [4], K-Medoids merupakan suatu algoritma untuk menemukan medoids didalam sebuah kelompok (cluster) [4] dan dinilai memiliki karakteristik penting dapat menghitung medoids menggunakan frekuensi kemunculannya [5], Self Organizing Map (SOM) merupakan Unsupervised Learning, dimana perubahan bobot-bobot interkoneksinya sebagai tanggapan terhadap masukan dan tanpa memerlukan jawaban targetnya [6], dan Fuzzy C-Means menggunakan model pengelompokkan fuzzy sehingga data dapat menjadi anggota dari semua kelas atau cluster terbentuk dengan derajat atau tingkat keanggotaan yang berbeda antara 0 hingga 1 [4] diusulkan oleh banyak peneliti [7] untuk strategi pemasaran.

K-Means clustering ialah salah satu metode cluster analysis non hirarki yang mempartisi objek yang ada kedalam satu atau lebih cluster atau kelompok objek berdasarkan karakteristiknya [9], $K$ -
Medoids memiliki kelebihan pada prediksi non-linear, kuat di parallel processing dan kemampuan untuk mentoleransi kesalahan, tapi memiliki kelemahan pada perlunya data training yang besar, overfitting, lambatnya konvergensi, dan sifatnya yang local optimum [4] SOM punya kelebihan ditingginya akurasi prediksi meskipun menggunakan data yang sedikit, akan tetapi SOM memiliki kelemahan pada prediksi data yang sifatnya naik turun secara fluktuatif seperti pada data UMKM [8].

$K$-Means dapat memecahkan masalah FCM dan SOM, yaitu over-fitting, lambatnya konvergensi, dan sedikitnya data training [7], yang mana ini tepat untuk karakteristik data UMKM pada tulisan ini. Tetapi K-Means memiliki kelemahan pada hasil sensitif pada pemilihan pusat clustering awal dan perhitungan solusi lokal untuk mencapai kondisi optimal [7].

Particle Swarm Optimization (PSO) adalah metode optimisasi yang terbukti efektif digunakan untuk memecahkan masalah optimisasi multidimensi dan multiparameter pada pembelajaran pada machine learning seperti di NN, SVM, dan classifier lain [8].

Pada penelitian ini PSO akan diterapkan untuk menemukan pusat cluster baru sesuai dengan jumlah cluster yang sudah ditentukan untuk melakukan optimasi $K$ Means clustering.

\section{METODOLOGI PENELITIAN}

Data yang digunakan pada penelitian ini adalah data sekunder dari UMKM 
Kabupaten Tasikmalaya yang didapatkan dari beberapa sumber diantaranya adalah:

a. Studi literatur

Pada tahap awal penelitian dilakukan studi literatur pada jurnal, buku, dengan penelitian terdahulu berkaitan dengan bahasan data mining.

b. Pengambilan Data

Pada penelitian ini, menggunakan data UMKM Kabupaten Tasikmalaya. Terdiri dari 8 atribut bertipe polynominal seperti yang ditunjukan pada Tabel 1 .

Tabel 1. Deskripsi Atribut Data UMKM

\begin{tabular}{|l|l|l|}
\hline No & Atribut & Tipe \\
\hline 1 & Nama usaha & Polynominal \\
\hline 2 & Bidang usaha & Polynominal \\
\hline 3 & Produk barang & Polynominal \\
\hline 4 & Cara berbisnis & Polynominal \\
\hline 6 & Omset & Polynominal \\
\hline 7 & Aset & Polynominal \\
\hline 8 & Status usaha & Polynominal \\
\hline 9 & Kecamatan & Polynominal \\
\hline
\end{tabular}

c. Pengolahan Data

Pada tahap ini dilakukan beberapa tahapan, dimulai dari mengkonversi data pada tahapan transformasi data dari polynominal ke numerik dengan data cleaning, kemudian untuk tahapan $K$ Means, dan tahapan PSO serta tahapan klasifikasi menggunakan SVM.

d. Pengolahan data, transformasi data dan data cleaning

Pada tahap ini dilakukan transformasi dari data bertipe nominal ke data bertipe numerik, selanjutnya dilakukan proses cleaning data dengan melakukan pengisian missing value pada data tersebut. Pengisian missing value dapat ditangani dengan menggunakan metode mean (ratarata), median (nilai tengah) dan most frequent (nilai yang sering muncul). Pada kali ini, missing value diisi menggunakan metode most frequent atau yang sering muncul, sebab separuh dari data tersebut merupakan data yang bersifat nominal.

e. Tahapan algoritma K-Means

Algoritma K-Means digunakan untuk proses clustering pada atribut yang memiliki data kontinu menjadi kategorikal berupa cluster. Untuk menentukan jumlah $\mathrm{k}$-cluster dilakukan dengan percobaan $\mathrm{k}=$ 2, 3, 4, 5. Untuk menilai kualitas jumlah kcluster. Peneliti menggunakan klasifikasi SVM dan dipilih yang memiliki tingkat akurasi tertinggi yaitu dibagi menjadi 2 cluster. Tahapan dalam proses algoritma $K$-Means diantaranya:

1) Menentukan banyak cluster yang akan dibentuk.

2) Menentukan $k$-centroid (titik pusat cluster) secara acak.

3) Menghitung jarak setiap data terhadap masing-masing centroid. Rumus yang digunakan yaitu rumus Euclidean dengan persamaan (11).

$$
\begin{aligned}
& D(x 1, x 2) \\
& =\sqrt{\sum_{i}^{n}=1(x 1-x 2)^{2}}
\end{aligned}
$$

Dimana:

$D\left(x_{1}, x_{2}\right)=$ dimensi data

$x_{1} \quad=$ posisi titik 1

$x_{2} \quad=$ Posisi titik 2

4) Mengelompokan data berdasarkan jarak terdekat antara data dan centroid.

5) Menentukan nilai centroid yang baru dengan menghitung rata-rata dari cluster yang bersangkutan menggunakan persamaan (2). 
JURNAL NUANSA INFORMATIKA

Volume 15 Nomor 2, Juli 2021

$$
c_{k}=\frac{1}{n_{k}} \sum d_{1}
$$

Dimana:

$$
\begin{aligned}
n_{k}= & \text { Jumlah data dalam } \\
& \text { cluster } \mathrm{k} \\
d_{i}= & \text { Jumlah nilai jarak } \\
& \text { yang masuk dalam } \\
& \text { masing-masing } \\
& \text { cluster. }
\end{aligned}
$$

6) Melakukan perulangan dari langkah 3-5 hingga anggota tiap cluster tidak ada yang berubah.

Data yang dihasilkan dari proses $K$ Means ini akan digunakan pada proses selanjutnya yaitu proses seleksi fitur menggunakan algoritma PSO.

f. Tahapan Particle Swarm Optimization

Setelah dilakukan proses clustering akan dilakukan seleksi fitur menggunakan algoritma Particle Swarm Optimization (PSO). PSO sebagai algoritma yang digunakan untuk optimasi, menyediakan prosedur pencarian berbasis populasi dimana individu disebut dengan partikel [7]. Partikel yang mewakili solusi kandidat dapat berpindah ke posisi optimal dengan memperbaharui posisi dan kecepatannya [6].

1) Inisialisasi kecepatan, posisi, pbest, gbest setiap partikel secara acak yang diatur dalam rentang yang telah ditentukan.

2) Hitung fitness dari partikel menggunakan rumus fungsi fitness pada persamaan.

$$
\begin{aligned}
& \text { Fitness } \\
& =\frac{\text { jumlah instance yang diklasifika }}{3} \\
& \text { jumlah instance })
\end{aligned}
$$

p-ISSN : 1858-3911, e-ISSN : 2614-5405

https://journal.uniku.ac.id/index.php/ilkom

3) Perbaharui memori dengan memodernisasi pBest dan gBest berdasarkan fungsi fitness Persamaan (4) dan Persamaan (5).

If $($ pos $>$ pBest $): p B e s t=p o s \ldots$

If $($ pos $>g$ Best $)=$ pos ...

4) Perbaharui kecepatan $v \frac{\text { new }}{i d}$ dengan persamaan (6).

$v \frac{n e w}{i d}=w \cdot v \frac{o l d}{i d}+c_{1} \cdot r_{2}$

Dimana Perbaharui $v \frac{\text { old }}{i d}$ adalah kecepatan lama $x \frac{\text { noldew }}{i d}$ mewakili posisi partikel i.pBestadalah posisi dengan nilai objektif terbaik yang ditemukan oleh partikel $i$ dan seluruh populasi. $w$ digunakan untuk mengontrol perilaku konvergensi PSO sementara $r_{1}$ dan $r_{2}$ adalah parameter acak berkisar antara 0 dan $1 . c_{1}$ dan $c_{2}$ menunjukan gerakan pada kontrol partikel.

5) Perbaharui posisi dengan persamaan (7) Perbarui posisi dengan rumus Sigmoid (S) dari kecepatan yang telah diperbaharui diatas dengan persamaan (17). Dalam penerapan algoritma PSO digunakan untuk solusi permasalahan seleksi fitur, maka dapat menggunakan binary digit untuk menunjukan fitur. Fitur yang tidak terpilih dilambangkan dengan 0 , sedangkan fitur terpilih dilambangkan 1 .

$S=\frac{-b \pm \sqrt{b^{2}-4 a c}}{1+e^{-v_{i d}^{\text {new }}}}$

$$
\begin{aligned}
& X_{i d}^{\text {new }} \\
& =\left\{\begin{array}{c}
1, \text { if Sigmoid }(S)>\text { rand }(0,1)>0.5 \\
0, \text { Otherwise }
\end{array}\right.
\end{aligned}
$$


Dalam penelitian ini menggunakan inisialisasi populasi partikel secara acak yaitu:

$$
X_{i d}^{\text {new }}=\left\{\begin{array}{c}
1, \text { if } U(0,1)>0.5 \\
0, \text { Otherwise }
\end{array}\right.
$$

6) Perulangan berhenti ketika mencapai iterasi maksimal. Atribut hasil seleksi didapat dengan mengambil nilai fitness tertinggi (dengan nilai cost terendah) dari semua literasi.

Data yang dihasilkan dari seleksi fitur ini akan digunakan pada proses selanjutnya yaitu proses klasifikasi menggunakan algoritma SVM.

g. Pembagian data training dan data testing

Tahap pembagian data menggunakan metode random sampling. Random sampling menurut Kerlinger [9] adalah metode penarikan dari sebuah populasi atau semesta dengan cara tertentu sehingga setiap anggota populasi atau semesta tadi memiliki peluang yang sama untuk terpilih atau terambil. Dengan membagi data latih sebesar $70 \%$ dan data uji $30 \%$.

\section{h. Tahap Support Vector Machine}

Hasil seleksi fitur, yaitu atribut terpilih akan digunakan dalam proses klasifikasi menggunakan algoritma SVM untuk membuat suatu model dari set data training yang digunakan untuk memprediksi kelas dari suatu data baru.

Tahapan-tahapan algoritma SVM dalam mengklasifikasikan dataset adalah sebagai berikut:

1) Mempersiapkan data training. Data training terdiri dari $70 \%$ dari keseluruhan data set.

2) Menemukan batas antar kelas. Ketika setiap titik dalam kelas dihubungkan dengan titik yang lain, maka akan muncul garis yang memisahkan antar kelas tersebut Batas ini disebut convex hull. Setiap kelas memiliki convex hull sendiri dan karena kelas (diasumsikan) linear terpisah, hull ini tidak saling berpotongan.

3) Menentukan hyperplane yang memaksimalkan margin antar kelas. Dapat dilakukan dengan cara sebagai berikut:

a) Pertama, hyperplane apapun dinyatakan dalam dua atribut, $x_{1}$ dan $x_{2}$, seperti ditunjukan pada persamaan (8).

$w \cdot x+0 \ldots$

Keterangan:

$$
\begin{aligned}
\mathrm{W} & =\operatorname{bobot}\left(w=w_{1}, w_{1}, \ldots, w_{n},\right. \\
\mathrm{X} & =\text { jumlah atribut }\left(x_{1}, x_{2}, \ldots, x_{n},\right. \\
\mathrm{B} & =\text { bias }
\end{aligned}
$$

b) Sebuah hyperplane optimal, didefinisikan secara unik oleh $b_{0,}+w_{0} . X=0 . \quad$ Setelah mendefinisikan hyperplane dalam metode ini, dapat menunjukkan margin-nya sesuai dengan persamaan.

$\operatorname{margin}=\frac{2}{\sqrt{x_{1}}} \cdot x_{1} \ldots$

c) Memaksimalkan kuantitas ini membutuhkan pemrograman kuadrat, yang merupakan proses berkedudukan kuat dalam teori optimasi matematika. Selanjutnya $W$ dapat dengan mudah dinyatakan dalam beberapa contoh data pelatihan, yang dikenal sebagai support vector, sesuai dengan persamaan (). 
JURNAL NUANSA INFORMATIKA

Volume 15 Nomor 2, Juli 2021
p-ISSN : 1858-3911, e-ISSN : 2614-5405

https://journal.uniku.ac.id/index.php/ilkom
4) Menentukan batas dan hyperplane, setiap tes baru dapat diklasifikasikan dengan menghitung disisi mana hasil data tersebut dalam hyperplane. Hal ini dapat ditemukan dengan menggantikan contoh tes $\mathrm{x}$ ke dalam persamaan hyperplane tersebut. Jika terhitung +1 , maka termasuk kelas positif dan jika terhitung -1 maka termasuk ke dalam kelas negatif. Kemudian model akan dievaluasi untuk mengetahui hasil akurasi.

i. Tahapan mining data

Pada tahap ini dilakukan pengklasifikasi menggunakan algoritma SVM pada data UMKM tanpa menerapkan algoritma $K$ Means dan juga PSO serta dilakukan juga pengklasifikasian pada data UMKM menggunakan algoritma SVM dengan menerpakan K-Means dan algoritma PSO untuk mengetahui peningkatan akurasi yang dihasilkan.

j. Tahapan Evaluasi

Perhitungan akurasi dilakukan menggunakan confusion matrix dengan cara menghitung jumlah data diklasifikasikan dengan dibagi dengan jumlah prediksi yang dilakukan. Adapun langkah-langkah sebagai berikut:

1) Masukan hasil pengujian klasifikasi pada tabel confusion matrix seperti pada tabel berikut:

Tabel 2 Pengujian Confusion Matrix

\begin{tabular}{|l|l|l|l|l|}
\hline Klasifikasi & \multicolumn{4}{|l|}{ Kelas hasil prediksi } \\
\hline Kelas actual & & Ya & Tidak & Jumlah \\
\cline { 2 - 5 } & Ya & TP & FN & P \\
\cline { 2 - 5 } & Tidak & FP & TN & N \\
\hline
\end{tabular}

Keterangan:

True Positive : Jumlah kasus positif yang diklasifikasikan sebagai positif.

False : Jumlah kasus negatif

Positive (FP) yang diklasifikasikan

sebagai positif.

True

Negative

(TN)

False

Negative

(FN)

Positive (P) : Jumlah kasus positif.

Negative $(\mathrm{N})$ : Jumlah kasus negatif.

2) Hitung nilai akurasi menggunakan persamaan

$$
\text { Accuracy }=\frac{T P+T N}{P+N} X 100 \% \ldots
$$

3) Nyatakan kesimpulan dan hasil akurasi yang diperoleh

k. Penarikan Kesimpulan

Penarikan kesimpulan didasarkan pada studi pendahuluan, pengumpulan data dan pengembangan aplikasi serta hasil analisis dari penelitian. Kesimpulan yang diperoleh adalah tentang bagaimana pengaruh penerapan algoritma K-Means dan PSO terhadap tingkat akurasi dan waktu pemrosesan pada algoritma SVM dalam strategi pemasaran. Sehingga dapat diketahui pengaruh dan hasil akurasi dan lama waktu pemrosesan dari sebelum dan sesudah penerapan algoritma $K$-Means dan PSO pada algoritma SVM.

\section{HASIL DAN PEMBAHASAN}

Industri kreatif di Indonesia dapat berkembang dengan baik melalui 3 (tiga) unsur penting yang bersinergi dan saling mendukung yaitu pemerintah, pelaku bisnis dan cendekiawan.

Penelitian ini menggunakan data UMKM industri kreatif sebanyak seribu tiga ratus dua puluh tiga, data tersebut 
dibagi ke dalam data training dan data

$<300.000 .000$ 2 testing.

\section{A. Missing value handling}

Pada tahap ini, dilakukan penanganan terhadap missing value pada data. Penanganan missing value dilakukan dengan mengisi data yang kosong menggunakan metode most frequent atau nilai yang sering muncul.

Pengisian missing value dilakukan dengan mengganti nilai yang missing value dengan nilai yang memiliki frekuensi muncul paling banyak dalam sebuah atribut.

B. Transformasi data

Transformasi data dilakukan untuk mengubah data dari data yang bertipe nominal ke numerik. Data yang diubah antara lain:

Tabel 3. Transformasi Atribut

\begin{tabular}{|l|c|c|}
\hline Jenis Usaha & Frekuensi & Transformasi \\
\hline Kuliner & 579 & 1 \\
\hline Lain-lain & 227 & 2 \\
\hline Kerajinan & 183 & 3 \\
\hline Fashion & 162 & 4 \\
\hline Desain Produk & 56 & 5 \\
\hline Desain Interior & 33 & 6 \\
\hline Fotografi & 23 & 7 \\
\hline Musik & 13 & 8 \\
\hline DKV & 10 & 9 \\
\hline Seni Rupa & 8 & 10 \\
\hline Penerbitan & 7 & 11 \\
\hline Seni Pertunjukan & 6 & 12 \\
\hline $\begin{array}{l}\text { Televisi dan } \\
\text { Radio }\end{array}$ & 4 & 13 \\
\hline $\begin{array}{l}\text { Film, animasi, } \\
\text { video, dll }\end{array}$ & 4 & 14 \\
\hline Periklanan & 3 & 15 \\
\hline Arsitektur & 3 & 16 \\
\hline $\begin{array}{l}\text { Aplikasi dan } \\
\text { Game Developer }\end{array}$ & 1 & 17 \\
\hline
\end{tabular}

Tabel 4. Transformasi Atribut (Omset)

\begin{tabular}{|l|c|}
\hline Omset & Transformasi \\
\hline $300.000 .000-2.5$ Milyar & 1 \\
\hline
\end{tabular}

Tabel 5. Transfromasi Atribut (Aset)

\begin{tabular}{|l|r|}
\hline Aset & Omset \\
\hline$<50.000 .000$ & 1 \\
\hline $50.000 .000-500.000 .000$ & 2 \\
\hline$>500.000 .000$ & 3 \\
\hline
\end{tabular}

Kemudian aturan tersebut diterapkan pada dataset UMKM. Hasil transformasi data tersebut ditampilkan pada Tabel 8 .

Tabel 6. Hasil Transformasi Data

\begin{tabular}{|l|l|l|l|l|l|}
\hline \multicolumn{1}{|c|}{ Atribut } & \multicolumn{5}{c|}{ Dataset } \\
\hline Jenis Usaha & 2 & 4 & 1 & $\ldots$ & 1 \\
\hline Omset & 1 & 2 & 1 & $\ldots$ & 1 \\
\hline Aset & 3 & 3 & 2 & $\ldots$ & 1 \\
\hline
\end{tabular}

\section{Tahap Clustering}

Pada tahap clustering dibentuk cluster menggunakan algoritma K-Means. Tahap ini akan diambil atribut jenis usaha, aset, dan omset sebagai contoh dalam proses clustering yaitu data ke-1 sampai data ke10 dapat dilihat pada tabel 9.

Tabel 7. Sampel Data untuk Proses Clustering

\begin{tabular}{|c|c|}
\hline $\begin{array}{l}\text { Data- } \\
\text { Ke }\end{array}$ & Aset \\
\hline 1 & 48000000 \\
\hline 2 & 7000000 \\
\hline 3 & 62000000 \\
\hline 4 & 48000000 \\
\hline 5 & 51000000 \\
\hline 6 & 60000000 \\
\hline 7 & 68000000 \\
\hline 8 & 24000000 \\
\hline 9 & 52000000 \\
\hline 10 & 53000000 \\
\hline
\end{tabular}

Adapun tahapan dalam proses algoritma K-Means:

1) Menentukan jumlah $k$-cluster yang akan dibentuk

Dalam hal ini jumlah $k$-cluster yang digunakan yaitu $\mathrm{k}=2$. 
JURNAL NUANSA INFORMATIKA

Volume 15 Nomor 2, Juli 2021
p-ISSN : 1858-3911, e-ISSN : 2614-5405

https://journal.uniku.ac.id/index.php/ilkom

2) Membangkitkan $k$-centroid (titik pusat cluster) secara acak.

Pusat awal cluster digunakan sebagai sample perhitungan yaitu:

1. Data ke- $3=\mathrm{c} 0=62000000$

2. Data ke- $8=\mathrm{c} 1=24000000$

3) Menghitung jarak setiap data terhadap masing-masing centroid. Rumus yang digunakan yaitu rumus Euclidean dengan persamaan (21).

$\mathrm{D}\left(x_{1, x_{2}}\right)=\sqrt{\sum_{i=1}^{n}\left(x_{2}-x_{1}\right)^{2}} \ldots$

Dimana:

$D\left(x_{2}, x_{1}\right)$ : Dimensi data (jarak data)

$x_{1} \quad$ : Posisi pusat cluster

$x_{2} \quad$ : Posisi objek data

$I d-0=c 0$

$=\sqrt{(48000000-62000000)^{2}}$

$=14000000$

$c 1=\sqrt{(48000000-24000000)^{2}}$ $=24000000$

$I d-1=c 0$

$=\sqrt{(7000000-62000000)^{2}}$

$=55000000$

$c 1=\sqrt{(7000000-24000000)^{2}}$ $=17000000$

Ulangi langkah 3 sampai semua anggota atribut ter-cluster sehingga menghasilkan data seperti Tabel 10.

Tabel 8. Hasil perhitungan jarak data terhadap pusat cluster

\begin{tabular}{|c|c|c|c|c|}
\hline Id & Aset & Co & C1 & $\begin{array}{c}\text { Jarak } \\
\text { Terdek } \\
\text { at }\end{array}$ \\
\hline 0 & 48000000 & 14000000 & 24000000 & 14000000 \\
\hline 1 & 7000000 & 55000000 & 17000000 & 17000000 \\
\hline 2 & 62000000 & 0 & 38000000 & 0 \\
\hline 3 & 48000000 & 14000000 & 24000000 & 14000000 \\
\hline 4 & 51000000 & 11000000 & 27000000 & 11000000 \\
\hline
\end{tabular}

\begin{tabular}{|c|c|c|c|c|}
\hline 5 & 60000000 & 2000000 & 36000000 & 2000000 \\
\hline 6 & 68000000 & 6000000 & 44000000 & 6000000 \\
\hline 7 & 24000000 & 38000000 & 0 & 0 \\
\hline 8 & 52000000 & 10000000 & 28000000 & 10000000 \\
\hline 9 & 53000000 & 9000000 & 29000000 & 9000000 \\
\hline
\end{tabular}

Keterangan: $\mathrm{C} 0=$ Cluster $1, \mathrm{C} 1=$ Cluster 2

4) Lalu dikelompokkan data berdasarkan jarak terdekat antara data dengan centroid. Hasil pengelompokkan dapat dilihat pada table berikut:

Tabel 9. Hasil pengelompokan untuk

\section{iterasi 1}

\begin{tabular}{|c|c|c|}
\hline Data ke- & C0 & C1 \\
\hline 1 & 1 & 1 \\
\hline 2 & & \\
\hline 3 & 1 & \\
\hline 4 & 1 & \\
\hline 5 & 1 & \\
\hline 6 & 1 & \\
\hline 7 & & 1 \\
\hline 8 & 1 & \\
\hline 9 & 1 & \\
\hline 10 & & \\
\hline
\end{tabular}

Keterangan: $\mathrm{C} 0=$ Cluster $1, \mathrm{C} 1=$ Cluster 2, C2 = Cluster 3

5) Menentukan nilai centroid yang baru dengan menghitung rata-rata dari cluster yang dihasilkan pada iterasi 1 menggunakan persamaan (22).

$\left(x_{1}=\frac{1}{\left(n_{k}\right)} \sum\left(d_{i}\right) \ldots\right.$

Dimana:

$n_{k} \quad$ : Jumlah data dalam cluster $\mathrm{k}$.

$d_{i} \quad$ : Jumlah nilai jarak yang masuk dalam masingmasing cluster.

Adapun hasil diperhitungkan untuk menentukan pusat cluster baru sebagai berikut:

1. Cluster $1=$ $\underline{\text { (data } 1+\text { data } 2+\text { data } 3+\text { data } 6+\text { data } 7+\text { data8+data9+data10) }}$ 8 
inersia $(W)=0.9$, koefisien 1 $\frac{(48000000+62000000+48000000+51000000+60000000+68000000+52000090)}{8} \neq=0.5$, dan koefisien akselerasi

55,25

2. Cluster $2=\frac{\text { (data } 2+\text { data } 8)}{2}$

$$
=\frac{(7000000+24000000)}{2}=12,50
$$

6) Lakukan pengulangan dari langkah 3 5 hingga anggota tiap cluster tidak ada berubah.

7) Hasil dari data yang ter-cluster ini akan digunakan pada proses selanjutnya yaitu pada proses seleksi fitur menggunakan algoritma PSO.

D. Tahap seleksi fitur

Tahapan PSO digunakan untuk mencari fitur terbaik yang ada pada data UMKM. Fitur terbaik merupakan fitur terpilih yang digunakan untuk proses selanjutnya.

Adapun algoritma PSO untuk proses seleksi fitur (atribut) adalah sebagai berikut:

1) Input data untuk seleksi fitur, digunakan 5 atribut sebagai sample dari keseluruhan 25 atribut yang ada.

Tabel 10. Data UMKM yang akan

\section{diseleksi fitur}

\begin{tabular}{|c|c|c|c|c|}
\hline $\begin{array}{l}\text { Bidang } \\
\text { Usaha }\end{array}$ & Omset & Aset & Omset & $\begin{array}{l}\text { Hak } \\
\text { Milik }\end{array}$ \\
\hline 0 & 3 & 1 & 0 & 1 \\
\hline 2 & 3 & 4 & 0 & 1 \\
\hline 1 & 1 & 2 & 0 & 0 \\
\hline 0 & 0 & 4 & 1 & 0 \\
\hline 0 & 1 & 2 & 0 & 1 \\
\hline 1 & 3 & 1 & 0 & 1 \\
\hline 1 & 2 & 3 & 1 & 0 \\
\hline 1 & 1 & 1 & 0 & 0 \\
\hline 1 & 2 & 1 & 0 & 1 \\
\hline 1 & 3 & 0 & 1 & 0 \\
\hline
\end{tabular}

2) Jumlah partikel yang ditetapkan sebanyak 30 partikel dan iterasi sebanyak 100.

3) Misal sampel sebanyak 3 partikel. Inisialisasi posisi setiap $\left(x_{t}\right)$, bobot
$2\left(C_{2}\right)=0.5$. Pada tahap awal kecepatan partikel $\left(V_{t}\right)=0$. Posisi tiap partikel di inisialisasi seperti berikut:

Partikel $1=$ [01111]

Partikel $2=[10110]$

Partikel $3=$ [11011]

4) Hitung fitness dari partikel menggunakan algoritma SVM. Nilai fitness tiap partikel:

Partikel $1=[01111]=0.95$

Partikel $2=[10110]=0.850$

Partikel $3=[11011]=0,850$

5) Tuliskan nilai pbest masing-masing partikel berdasarkan nilai akurasi yang dihasilkan SVM. Tentukan gbest berdasarkan nilai pbest tertinggi.

pbest Partikel $1=[01111]=0,925$

pbest Partikel $2=[10110]=0,850$

pbest Partikel $3=[11011]=0,800$

berdasarkan nilai pbest diatas maka nilai gbest $=0,925$

6) Hitung kecepatan dan posisi partikel menggunakan Persamaan (23)

$v_{i d}^{\text {new }}=\mathrm{W} \cdot v_{i d}^{\text {new }}+C_{1} \cdot r_{1}\left(p b_{i d}^{\text {old }}-\right.$ $\left.x_{i d}^{o l d}\right)+c_{2} \cdot r_{2}\left(g b_{i d}^{o l d}-x_{i d}^{o l d}\right) .$.

Dimana $r_{1}$ dan $r_{2}$ merupakan nilai random antara 0-1. Misal $r_{1}=0.6$ dan $r_{2}=0.6$.

$$
\begin{aligned}
\text { Kecepatan }= & 0.9+0 \\
\text { partikel 1 } & +0,5 \times 0,6(0,925 \\
& -0.925) \\
& +0,5 \times 0,6(0,925 \\
& -0,925) \\
= & 0
\end{aligned}
$$

7) Perbaharui posisi dengan Persamaan 
JURNAL NUANSA INFORMATIKA

Volume 15 Nomor 2, Juli 2021
p-ISSN : 1858-3911, e-ISSN : 2614-5405

https://journal.uniku.ac.id/index.php/ilkom
Perbaharui posisi dengan rumus sigmoid ( $\mathrm{S}$ ) dari kecepatan yang telah diperbaharui diatas dengan Persamaan. Dalam penerapan algoritma PSO digunakan untuk solusi permasalahan seleksi fitur, maka dapat menggunakan binary digit untuk menunjukan fitur. Fitur yang tidak terpilih dilambangkan dengan sedangkan fitur terpilih dilambangkan 1 .

8) Perulangan berhenti ketika mencapai nilai maksimal. Atribut nilai seleksi didapat dengan mengambil nilai fitness tertinggi dari semua iterasi.

9) Data yang dihasilkan dari proses seleksi fitur menggunakan PSO ini akan digunakan untuk proses selanjutnya yaitu proses klasifikasi menggunakan algoritma SVM.

E. Tahap pembagian data

Tahap ini merupakan proses membagi data set menjadi 2 (dua) bagian, yaitu data training dan data testing dengan proporsi 70:30 dalam pembagian data UMKM.

F. Tahap evaluasi dengan confusion matrix

Evaluasi dengan confusion matrix dilakukan untuk mengetahui tingkat akurasi dari perhitungan yang sudah dilakukan dalam penelitian. Adapun langkahnya adalah sebagai berikut:

1. Masukan hasil pengujian pada tabel confusion matrix seperti pada Tabel 13.

Tabel 11. Confusion matrix

\begin{tabular}{|l|c|c|c|c|}
\hline Klasifikasi & \multicolumn{4}{|c|}{ Kelas hasil klasifikasi } \\
\hline \multirow{2}{*}{$\begin{array}{l}\text { Kelas } \\
\text { aktual }\end{array}$} & & Ya & Tidak & Jumlah \\
\cline { 2 - 5 } & Ya & 70 & 0 & 71 \\
\cline { 2 - 5 } & Tidak & 1 & 49 & 49 \\
\hline
\end{tabular}

2. Hitung nilai akurasi menggunakan persamaan (20)

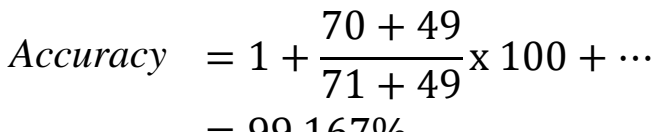

$$
=99,167 \%
$$

\section{G. Tahap Mining Data}

Dalam tahap ini dilakukan proses mining data. Pertama untuk proses klasifikasi menggunakan algoritma SVM tanpa menggunakan K-Means dan PSO. Kedua proses klasifikasi menggunakan algoritma SVM dengan menerapkan $K$ Means. Ketiga, proses klasifikasi menggunakan SVM menggunakan $K$ Means clustering dan PSO. Kemudian seluruh proses klasifikasi dimasukkan dalam confusion matrix untuk mengetahui tingkat akurasi, kemudian diukur waktu pemrosesannya pada saat melakukan proses masing-masing klasifikasi.

\section{H. Hasil Algoritma SVM}

Penerapan klasifikasi yang pertama adalah dengan menerapkan algoritma SVM dengan perbandingan data training:data testing adalah 70:30 setelah dilakukan handling missing value pada data UMKM. Hasil akurasi yang didapatkan dari penerapan algoritma SVM dapat dilihat pada tabel.

Tabel 12. Akurasi algoritma SVM

\begin{tabular}{|l|l|l|}
\hline Algoritma & Hasil akurasi & $\begin{array}{l}\text { Waktu } \\
\text { pemrosesan }\end{array}$ \\
\hline SVM & $55.0 \%$ & 0.03 detik \\
\hline \multicolumn{2}{|c|}{ Penerapan algoritma SVM }
\end{tabular}

mendapatkan hasil akurasi sebesar 55.0\% dengan waktu pemrosesan selama 0,03 detik. Hasil akurasi ini masih dapat ditingkatkan lagi menggunakan SVM yang ditambahkan dengan $K$-Means clustering dan PSO sehingga dapat menghasilkan akurasi yang lebih baik.

I. Hasil K-Means pada SVM 
Algoritma $K$-Means digunakan sebagai proses clustering pada atribut yang memiliki data kontinu.

Tabel 13. Hasil akurasi dan waktu pemrosesan setiap k-cluster

\begin{tabular}{|l|c|c|c|}
\hline Algoritma & $\begin{array}{c}\text { Jumlah } \\
\text { k-cluster }\end{array}$ & Akurasi & $\begin{array}{c}\text { Waktu } \\
\text { Pemrosesan }\end{array}$ \\
\hline \multirow{3}{*}{ SVM $+K-$} & 2 & $95,83 \%$ & 0,63 detik \\
\cline { 2 - 4 } Means & 3 & $95,83 \%$ & 0,86 detik \\
\cline { 2 - 4 } & 4 & $92,50 \%$ & 0,97 detik \\
\cline { 2 - 4 } & 5 & $90,83 \%$ & 1,12 detik \\
\hline
\end{tabular}

\section{J. Hasil PSO pada SVM}

Hasil yang didapatkan oleh PSO dalam melakukan seleksi fitur kemudian digunakan untuk klasifikasi menggunakan SVM dengan menggunakan pembagian data yang sama seperti yang diterapkan pada proses penerpaan SVM sebelumnya. Hasil akurasi, waktu pemrosesan dan atribut yang terpilih yang dihasilkan pada proses ini. Pada proses ini menunjukkan lebih sedikit atribut yang terpilih maka akurasinya cenderung lebih tinggi.

\section{Tabel 14. Hasil akurasi, waktu} pemrosesan dan jumlah

\begin{tabular}{|c|c|c|c|c|}
\hline \multirow{2}{*}{$\begin{array}{c}\text { Algori } \\
\text { tma }\end{array}$} & $\begin{array}{c}\text { Ekse } \\
\text { kusi } \\
\text { ke }\end{array}$ & Akurasi & $\begin{array}{c}\text { Waktu } \\
\text { Pemrosesan }\end{array}$ & $\begin{array}{c}\text { Atribut } \\
\text { Terpilih }\end{array}$ \\
\hline \multirow{5}{*}{} & 1 & $99,17 \%$ & 34,99 detik & 15 \\
\cline { 2 - 5 } & 2 & $99,17 \%$ & 32,48 detik & 14 \\
\cline { 2 - 5 } & 3 & $99,17 \%$ & 33,07 detik & 13 \\
\cline { 2 - 5 } SVM+ & 4 & $99,17 \%$ & 33,28 detik & 14 \\
\cline { 2 - 5 } & 5 & $99,17 \%$ & 35,64 detik & 15 \\
\cline { 2 - 5 } & 7 & $98,33 \%$ & 34,66 detik & 16 \\
\cline { 2 - 5 } & 8 & $99,33 \%$ & 34,19 detik & 15 \\
\cline { 2 - 5 } & 9 & $99,17 \%$ & 32,62 detik & 15 \\
\cline { 2 - 5 } & 10 & $98,33 \%$ & 34,38 detik & 16 \\
\cline { 2 - 5 } & $\begin{array}{c}\text { Rata- } \\
\text { rata }\end{array}$ & $98,92 \%$ & 33,87 detik & 14,8 \\
\hline
\end{tabular}

Hasil akurasi yang dihasilkan algoritma SVM tanpa menggunakan K-Means dan PSO adalah 45,0\%. Kemudian akurasi tertinggi yang dihasilkan algoritma SVM dengan menggunakan PSO adalah 98,17\% dengan 14 atribut terpilih dan waktu pemrosesan tercepat adalah 22,48 detik. Sementara hasil akurasi tertinggi pada algoritma SVM dengan menggunakan $K$ Means dan PSO adalah $100 \%$ dengan 15 atribut terpilih dan waktu pemrosesan tercepat adalah 11,54 detik.

Sehingga terjadi peningkatan akurasi sekitar $43 \%$ antara sebelum menggunakan PSO dan sesudah menggunakan PSO dan terjadi percepatan waktu pemrosesan sekitar 10 detik dari hanya menggunakan SVM dan PSO dengan setelah menggunakan SVM dengan menggunakan K-Means dan PSO dalam melakukan klasifikasi UMKM.

K. Hasil K-Means dan PSO pada SVM

Data yang telah dilakukan handling missing value selanjutnya akan dilakukan proses pengelompokan menggunakan algoritma $K$-Means clustering. Setelah itu dilakukan proses PSO untuk memilih fitur terbaik. Fitur yang terpilih tersebut kemudian digunakan untuk proses klasifikasi menggunakan algoritma SVM. Setelah diklasifikasi kemudian dilakukan perhitungan akurasi menggunakan metode confusion matrix.

Tabel 15. Hasil akurasi dan waktu pemrosesan algoritma SVM dengan $K$ -

\begin{tabular}{|l|c|c|c|c|}
\hline \multicolumn{7}{|c}{ Means dan PSO } \\
\hline \multirow{4}{*}{$\begin{array}{c}\text { Algor } \\
\text { itma }\end{array}$} & $\begin{array}{c}\text { Eks } \\
\text { eku } \\
\text { Si } \\
\text { ke }\end{array}$ & $\begin{array}{c}\text { Akuras } \\
\text { i }\end{array}$ & $\begin{array}{c}\text { Waktu } \\
\text { Pemrosesa } \\
\mathbf{n}\end{array}$ & $\begin{array}{c}\text { Atribu } \\
\mathbf{t} \\
\text { Terpili } \\
\mathbf{h}\end{array}$ \\
\hline \multirow{4}{*}{$\begin{array}{l}\text { SVM } \\
+K-\end{array}$} & 1 & $99,17 \%$ & 13,15 detik & 20 \\
\cline { 2 - 6 } $\begin{array}{l}\text { Mean } \\
\text { s+PS }\end{array}$ & 2 & $99,17 \%$ & 12,68 detik & 21 \\
\cline { 2 - 6 } O & 3 & $99,17 \%$ & 12,70 detik & 21 \\
\cline { 2 - 5 } & 4 & $100 \%$ & 12,84 detik & 19 \\
\cline { 2 - 5 } & 6 & $97,50 \%$ & 12,42 detik & 21 \\
\cline { 2 - 5 } & 7 & $100 \%$ & 12,54 detik & 19 \\
\cline { 2 - 5 } & 8 & $99,17 \%$ & 13,15 detik & 20 \\
\hline
\end{tabular}


JURNAL NUANSA INFORMATIKA

Volume 15 Nomor 2, Juli 2021
p-ISSN : 1858-3911, e-ISSN : 2614-5405

https://journal.uniku.ac.id/index.php/ilkom

\begin{tabular}{|c|c|c|c|c|}
\hline & 9 & $98,33 \%$ & 12,83 detik & 21 \\
\cline { 2 - 5 } & 10 & $98,33 \%$ & 13,17 detik & 22 \\
\cline { 2 - 5 } & $\begin{array}{l}\text { Rat } \\
\text { a- } \\
\text { rata }\end{array}$ & $98,80 \%$ & 12,82 detik & 20,4 \\
\hline
\end{tabular}

Hasil akurasi yang dihasilkan algoritma SVM tanpa menggunakan K-Means dan PSO adalah 50\%, kemudian akurasi tertinggi dihasilkan algoritma SVM dengan menggunakan PSO adalah $99,17 \%$.

\section{KESIMPULAN}

Berdasarkan hasil penelitian, kesimpulan yang diperoleh yaitu cara kerja algoritma K-Means yaitu dengan mengelompokkan setiap atribut kontinu pada Data UMKM dan pemilihan jumlah cluster dapat mempengaruhi hasil akurasi dan waktu pemrosesan yang diperoleh. Dalam 4 percobaan yaitu dengan menggunakan 2, 3, 4 dan 5 cluster, jumlah $\mathrm{k}$-cluster $=2$ memberikan hasil akurasi dan waktu pemrosesan yang lebih baik dibanding jumlah cluster yang lain. $K$ Means berpengaruh dalam peningkatan waktu pemrosesan pada saat klasifikasi karena $K$-Means mengatasi masalah persebaran data pada dataset. Setelah dilakukan proses clustering dengan algoritma $K$-Means, selanjutnya dilakukan proses seleksi fitur menggunakan Particle Swarm Optimization. Dalam proses ini menghasilkan 15-22 fitur yang terpilih dari 21 fitur yang ada. Semakin sedikit atribut yang terpilih maka menghasilkan akurasi yang semakin tinggi. Hasil dari proses seleksi fitur kemudian dilakukan proses klasifikasi menggunakan algoritma SVM yang menghasilkan sebuah model.

\section{SARAN}

1. Untuk penelitian lebih lanjut diharapkan dapat mengeksplorasi algoritma $K$-Means menjadi lebih baik pada saat klasifikasi.

2. Pengembangan lebih lanjut data dilakukan ujicoba dengan memanfaatkan tools data mining.

\section{UCAPAN TERIMA KASIH}

Terima kasih kepada Dinas Tenaga Kerja, Koperasi dan Usaha Kecil dan Menengah Kabupaten Tasikmalaya atas ijin pelaksanaan penelitian.

\section{DAFTAR PUSTAKA}

[1] Kerlinger. (2006). Asas-Asas Penelitian Behaviour. Edisi 3, Cetakan 7. Yogyakarta: Gadjah Mada University Press.

[2] Departemen Perdagangan Republik Indonesia. (2009). Laporan Studi Industri Kreatif Indonesia 2009.

[3] Darmastuti, R. (2012). Media Relations: Konsep, Strategi dan Aplikasi. Yogyakarta: ANDI.

[4] Sabzi A, Farjami Y, Zihayat M. (2011). An Improved Fuzzy KMedoids Clustering Algorithm with Optimized Number of Clusters. IEEE International Conference on Hybrid Intelligent System. Malacca.

[5] Aurora P, Deepali, Varshney S. (2016). Analysis of $K$-Means and $K$ Medoids Algorithm for Big Data. ScienceDirect Procedia Computer Science 
[6] Seiffert, U. 2002. Self-Organizing Neural Networks (Recent Advances and Applications. Germany: SpringerVerlag Company.

[7] Arbin N, Suhaimi NS, Mokhtar NZ, Othman Z. (2015). Comperative Analysis Between K-Means and KMedoids form Statistical Clustering. IEEE International Conference on Artificial Intelligence, Modelling and Simulation.
[8] Fadilla, I., Adikara, P. P., \& Perdana, R. S. (2018). Klasifikasi Penyakit Chronic Kidney Disease (CKD) dengan Menggunakan Metode Extreme Learning Machine (ELM). Jurnal Pengembangan Teknologi Informasi dan Ilmu Komputer.

[9] Madhulatha TS. (2012). An Overview on Clustering Methods. IOSR Journal of

Engineer. 